\title{
Are Voters Myopic? An Empirical Analysis
}

\author{
Richard Jankowski \\ Political Science Department, State University of New York, Fredonia, United States
}

Copyright $(2018$ by authors, all rights reserved. Authors agree that this article remains permanently open access under the terms of the Creative Commons Attribution License 4.0 International License

\begin{abstract}
There is abundant evidence that voters are relatively uninformed about government. But, economic retrospective voting, via the "miracle of aggregation", overcomes this problem in democracies. However, there is also evidence that voters are myopic. Hence, voters can be manipulated by an adept administration. I review past empirical studies of myopic voting. I argue that they are characterized by two limitations: one, they assume a unidimensional issue space; and two, they rely on ecological inference, because they use aggregate economic performance and election results to infer myopic voting. Achen and Bartels [1] update previous empirical studies by including an increased number of elections and using a control for the multidimensionality of the issue space, i.e., voters' choice is based on issues other than the economy. But their analysis, based on aggregate data, still requires an ecological inference. By contrast, Hellwig and Marinova [2] present a unique micro-level study, designed by them that measure the time-horizon of individuals and thus avoid the ecological inference problem. However, their study still assumes a unidimensional issue space. I address both the multidimensionality and ecological inference problems by retesting both the Achen and Bartels' and Hellwig and Marinova studies. I find the preponderance of evidence rejects the myopia hypothesis.
\end{abstract}

Keywords Myopia, Voting, Economic Retrospective Voting, Multidimensionality, Ecological Inference

\section{Introduction}

There is abundant evidence that the average citizen is uninformed about government and politics (Campbell et al., [3]; Jacobson, [4]; Bennett, [5]; and Delli Carpini and Keeter, [6]. For example, only about $50 \%$ of voters in a district even know the name of their representative, and even fewer know how their representative voted on any legislation. Therefore, there are a number of recent critiques of democracy have questioned the ability of voters to evaluate public policies, e.g., Caplan, [7]; Somin,
[8], and others. ${ }^{1}$

In response, a major defense of democracy is retrospective voting, because voters do not have to be fully informed about policies; they only have to make a retrospective evaluation of the consequences of various policies (Fiorina, [9]; Riker, [10]; and many others). In fact, with the "miracle of aggregation" (via the Condorcet Jury Theorem), only a minimally informed electorate is needed to produce correct choices. Thus, a large, poorly-informed electorate could make choices as well or better than a better-informed philosopher king or a small group of oligarchies.

In response to this defense of democracy, a number of critics have argued that retrospective economic voting is a seriously flawed control mechanism, because voters are myopic, i.e., have only a short-term memory (Nordhaus, [11]; Kramer, [12]; Fair, [13]; Tufte, [14]; and more recently Achen and Bartels, [1], Achen and Bartels, [15], and Bartels, [16]). And hence, it is argued that retrospective voting is not a viable mechanism for evaluating and controlling governments.

This claim of voter myopia is just the latest iteration of the debate, both philosophical and empirical, over the epistemic properties of democracies and has a long history. ${ }^{2}$ Classical political theory, starting with Plato and Aristotle, has for the most part denigrated democracy, because of the lack of informed judgments made by the average citizen.

I address the claim of myopic voters by evaluating the evidence produced by Achen and Bartels [1] in support of

\footnotetext{
1 The critique of democracy actually dominates in Western thought. Going back to Plato and Aristotle, the dominant view was that democracy is seriously flawed relative to oligarchy. However, with the Enlightenment there has been a revival of a defense of democracy. Most of modern day critiques of democracy do not want a philosopher king or oligarchy to rule, rather they want reforms of democracy.

2 There are other critiques of democracy that are not based on uninformed voters. Following Schattschneider, [17], a number of authors have noted the "scope and bias" problems associated with democracies. See Schlozman, Verba and Brady, [18], for the critique based on bias favoring the rich. See Olson, [19], for the scope argument that many groups fail to organize. Lastly, another criterion for evaluating democracies is procedural. Are the voting system and rules "fair." See Arrow, [20], and others who follow in this tradition.

I do not address these critiques. I focus exclusively on the epistemic critique that voters in general are uninformed.
} 
this claim. In particular, I focus on the claim of myopic voters when it comes to economic retrospective voting. I present evidence that the claim of myopic voting fails, because it makes two crucial assumptions: one, the tests for myopic voting assume that the policy space is unidimensional, i.e., only economic issues matter; and two, myopic voting is inferred from aggregate data on economic performance and election outcome. Hence, the ecological fallacy problem is endemic to this literature (Kramer, [21]).

\section{Retrospective Economic Voting}

Downs [22] finds that individuals have little incentive to vote or acquire political information, because of the low probability that their vote will make a difference. To provide an incentive to vote and acquire political information requires us to drop Downs' assumption of self-interested actors, and accept the proposition that most individuals are weakly altruistic (Jankowski, [23]). Additionally, one method to reduce the costs of acquiring political information is via economic retrospective voting (Kramer, [21]; Fiorina, [9], etc.). Voters, then, just evaluate the economic performance of an incumbent administration, without having to be informed about the competency of a challenger. A question arises as to what information of past economic performance of an administration is sufficient for citizens to effectively evaluate its competence. Some economists argue that short-term memory is adequate, while others argue that voters are myopic, and hence, subject to making mistakes and/or open to manipulation by administrations.

The economic argument is that it is rational for voters to just incorporate the last few years of an administration's performance, because it is the best predictor of future performance (e.g., Alesina and Rosenthal, [24]: 191-95; MacKuen, Erickson and Stimson, [25].) The determinants of changes in the economy entail both a deterministic component and a stochastic component. Hence, to be able to evaluate the performance of an administration one must extract the signal from the noise. Sims $[26,27]$ shows that the best predictor of the performance of an economy is a simple autoregressive (AR(1)) or moving average (MA(1)) process. These predictions of economic performance outperformed large simultaneous equation models of the economy. Hence, the rational voter trying to assess the competency of an administration would just employ a comparable procedure, and focus on recent (short-term) changes in the economy.

On the other hand, others have argued that voters are myopic, and hence, are subject to making mistakes and/or subject to manipulation by an administration, e.g., Achen and Bartels, 2016. There are two explanations for why voters are myopic. The first is that they lack the memory of earlier economic events (Sarafidis, [28]). In particular, it is argued that the media, during an election, report almost exclusively the economic performance during the current year, and do not report the long-term economic performance of an administration (Kayser and Peress, [29]; Gentzkow, [30]).

An alternative explanation is that voters use an "end-heuristic" which entails substituting election-year performance, because it is more readily available (Healy and Lenz, [31]). Because information acquisition is costly, voters use heuristics to reduce the cost of information in evaluating the performance of an administration. Healy and Lenz conduct a number of experiments to assess the impact of short-term indicators versus long-term, cumulative measures on evaluation of candidates. They find that if given long-term, cumulative performance information, voters would use it relative to short-term, election year performance. Hence, voters prefer to make their assessment in terms of the long-term performance of administrations, but lack the information to do so. Hence, under both versions of myopia, a media that informs voters of the long-term performance of administrations would overcome the myopia problem.

\section{Previous Empirical Tests}

Nearly all past empirical tests of the myopia hypothesis have found support for the hypothesis. (The exceptions are Hibbs [35] and Wlezien [36], but they do not include controls for the multidimensionality of the issue space.) I present evidence which rejects the myopia hypothesis. I first explain how my empirical analysis differs from past empirical studies.

There are two primary factors that differentiate the empirical studies of the myopia hypothesis: the measures of administration economic performance, and controls for the multidimensional issue space.

The measures of economic performance in all past studies were either per capita real GDP or per capita real disposable income. It is assumed that voters evaluate an incumbent administration in terms of either of these two measures. The primary difference between the two measures is that per capita GDP is a pre-fisc measure; while per capita disposable income is a post-fisc measure. Thus, the disposable measure is after taxes and transfer payments; while the per capita GDP is before taxes and transfers.

This difference is crucial because Blinder and Watson [34] present evidence that neither government fiscal nor monetary policies affect per capita GDP. By contrast, per capita disposable income reflects the tax and transfer policies implemented by different administrations.

Most early tests of myopic voters use per capita GDP. Kramer [21], who initiated the myopia claim, Nordhaus [11], and Fair [13] all base their findings of myopic voters on per capita GDP. The more recent studies use real per capita disposable income for the reason that governments have direct control over taxes and transfer payments. Thus, Bartels [16], Achen and Bartels [1] and Wlezien [36] all use the per capita disposable measure. The only example of an early proponent of per capita disposable income is Tufte 
[14], but because the measure is compiled starting in 1948, his sample of election years is only nine.

The other major criterion differentiating studies of myopic voters is their control for multidimensionality. Voters evaluate administrations not only in terms of their economic performance, but also non-economic factors such as abortion, war, moral and other criteria. Hence, non-economic factors must be included in any test of the preferences of voters. A number of studies, e.g., Kramer [21], Hibbs [49], Bartels [16] and Wlezien [36] do not include controls for non-economic criteria; they only test the economic performance of administrations.

The other studies, Nordhaus [11], Fair [13] use war years as a control for non-economic factors. War years adds a second dimension to the issue space, it but ignores issues such as abortion which is crucial in recent years; and states' rights which resulted in the South's transformation from solid-south Democratic to solid-south Republican over the past three decades.

Because of the small sample size in the empirical analysis, a single general measure of the multidimensional issue space is frequently used. Tufte [14] uses the presidential approval rating. But, it is highly correlated with the economic performance of administrations, and hence, is never statistically significant. Lastly, Abramowitz [34] suggests a "time-for-change" measure to reflect the multidimensionality of the issue space. It has been adopted by Achen and Bartels [1] in their empirical analysis, and they note this measure reflects non-economic considerations in voters' decisions.

\section{Empirical Analysis}

As noted above, there is a large body of evidence that voters are myopic when assessing incumbent representatives. I focus on the evidence provided by Achen and Bartels [1], and others that have the same format, because it is the most recent, and hence, includes the largest number of observations.

By contrast, Hellwig and Marinova [2] create their own survey which incorporates a measure of voter memory, and their vote choice in the 2012 election. They, thus, avoid the necessity of making an ecological inference as to the intention of voters. They find that voters tend to be uninformed, not myopic, about both election year and cumulative administration economic performance. Hence, manipulation of election year economic performance is problematic if voters are misinformed about even current economic conditions. They, however, do not control for the multidimensionality of the issues of importance to voters.

Achen and Bartels [1] and Bartels [16] argue that voters are myopic when they evaluate presidential performance. They find that the economic performance of an administration in the year of a presidential election correlates with vote margins, but that longer time horizons do not. Thus, economic retrospective voting is an inefficient heuristic used by the average voter. Hence, proponents of the myopic-voter viewpoint reject retrospective voting as a defense for a poorly-informed electorate in a democracy.

I retest Achen and Bartels' [1] analysis of economic performance, but I update their data with the results of the 2016 election. I use the same dependent variable, that is, the margin of victory between the two major parties. ${ }^{3}$ Following most of the literature, I assume that the president's party is held responsible for the economy. Hence, when the incumbent president is not running, the party's candidate is held responsible for the performance of the economy. The retrospective economic voting hypothesis is that the victory margin is a function of economic conditions during the term of the incumbent president. The better the economy is, the greater the margin of victory for the incumbent party's candidate. Following Achen and Bartels [1], and others, I use real, per capita disposable income as the measure of economic performance. This measure of economic performance is after taxes and transfers. This is the crucial measure because Alesina, Londregan and Rosenthal, [32], argue that holding a presidential administration responsible for the economy is irrational. They argue that a president's administration has little control of the economy. The Federal Reserve's Open Market Committee controls monetary policy, and hence, has the primary impact on the economy. ${ }^{4}$ Disposable income has the advantage that it is post-tax and transfers, which are partially controlled by the administration.

In their most recent study, Achen and Bartels (2016) do incorporate a control for non-economic factors. Following Abramowitz (2008), they test whether voters have a preference for a periodic change in the party in power. (Bartels, 2008) does not include this control. He only tests for the effects of economic conditions.) Thus, the longer a party is in office, the greater is the probability that they will lose an election. Thus, a dummy variable "time-for-change" reflecting party control of the presidency is used, for 4,8 , 12 or 20 years. Achen and Bartels ([1:152]) claim that this measure "reflects the cumulative effect of exhaustive agendas, personnel turnover and accumulated scandals."

Their "time-for-change" measure implies that voters have a long-term memory (up to 20 years) for non-economic factors; but only a short-term memory for economic performance. Moreover, their measure also reflects a multidimensional issue space. ${ }^{5}$

\footnotetext{
${ }^{3}$ I also tested the hypothesis with the share of total votes and a binary dummy (win, lose) as the dependent variable. Only the share of votes exhibits, as noted below, a statistically significant correlation with economic performance.

4 A president's administration has a role to play if the economy is in a liquidity trap, where monetary policy is no longer effective. Hence, fiscal policy is required (Krugman, [33]).

To test for multidimensionality, I also used a measure of presidential approval. It is correlated with vote margins, but is collinear with the change measure of Abramowitz [35], and presidential approval is dominated by the change measure.
} 
Table 1. Determinants of Margin of Victory/Loss

\begin{tabular}{|c|c|c|c|c|}
\hline 1.A & Election year & Last 2 years & Cumulative 3 years & Hibbs (80\%) \\
\hline Economic Performance & $5.758^{* *}$ & $3.278^{* * *}$ & 1.218 & $4.448^{* * *}$ \\
& $(1.941)$ & $(0.707)$ & $(0.661)$ & $-1.168)$ \\
\hline Constant & -2.598 & $-9.654^{*}$ & $(5.810$ & $(3.275$ \\
& $(3.070)$ & $(3.406)$ & .13 & .46 \\
\hline Adj-R ${ }^{2}$ & .33 & .56 & & $4.138^{* * *}$ \\
\hline 1.B & & & & $(0.777)$ \\
\hline Economic Performance & $6.490^{* * *}$ & $2.864^{* * *}$ & $-1.413^{* *}$ \\
& $(1.040)$ & $(.521)$ & & $(.314)$ \\
\hline Time-for-Change & $-1.760^{* * *}$ & $-1.206^{* *}$ & & 2.552 \\
& $(0.282)$ & $(.314)$ & & $(3.459)$ \\
\hline Constant & $8.982^{* *}$ & 0.585 & & .76 \\
\hline
\end{tabular}

*** Probability less than .001

** Probability less than 0.01

* Probability less than 0.05

As with all statistical analysis, I checked whether the dependent variable has a normal distribution, and the Shapiro-Wilk test indicated that it does. Likewise, my visual inspection of the plots indicated that the relationships are linear.

But additional sensitivity tests are necessary because of the small sample size. Small changes can have a major impact when the sample is so small. I conducted a number of robustness checks, and all proved negative. Since the tests reaffirmed the findings reported in the body of the text, i.e., they reject the myopia hypothesis, I report the sensitivity tests in an appendix.

Following Achen and Bartels [1], I analyze (Table 1A) four different measures of economic performance. Their election-year measure is the sum of growth in the second and third quarters of an election year. The last quarter is dropped because most fall after the election. The two-year measure is the cumulative growth in the last two years of an administration (quarters 9 through 15). The three-year measure is the cumulative growth over the quarters 3 through 15. The first two quarters of each administration are argued to be the responsibility of the previous administration. Lastly, there is Hibbs' [35] measure of the geometrically discounted performance, for the $3^{\text {rd }}$ through $15^{\text {th }}$ quarters of an administration. The discount rate used, following Achen and Bartels [1], is $80 \%$.

Table 1.A reports just the economic performance using the four different measures. I reproduce Achen and Bartels' [1] findings that economic performance in the year of an election is correlated with the victory margin, but the three-year cumulative change in disposable income is statistically insignificant. For Achen and Bartels [1], this difference implies that the electorate is myopic.

However, both the two-year and Hibbs' [35] measures are also statistically significant and moreover, explain more of the variance in the dependent variable (56 and 47\% compared to $33 \%$ for the election-year measure.)

Adding the measure for "time for change" (Table 1.B) the three measures of economic performance are all statistically significant. And moreover, the explained variance by the three models is approximately equal, ranging from 76 to $81 \%$. The election-year economic measure of Achen and Bartels [1] benefits the most from the addition of the "change" measure, as the explained variance increases from 33 to $81 \%$ with its inclusion. (Wlezien [37] also finds that the two-year horizons dominate the election-year measure, but his analysis does not include their control for a "time for change.")

Hence, the question is whether we can differentiate between the three time-horizons, and test the myopia argument, since the tests produce roughly comparable measures of explained variance and all are statistically significant. Achen and Bartels [1] offer such a test. They also find the long-term horizons models are statistically significant, and roughly comparable in total explained variance. They add their election year economic performance measure to regressions testing the long-time performance measures. They find that the election year measure is statistically significant, and the longer-term measures are statistically insignificant. Hence, they argue this is evidence for their myopia hypothesis.

Table 2. DV: Vote Margin

\begin{tabular}{|c|c|c|}
\hline Hibbs' Discount Rate $=80 \%$ & & $\begin{array}{c}-.137 \\
(2.479)\end{array}$ \\
\hline Two Year Performance & 1.067 & \\
& $(1.028)$ & \\
\hline Election Year Performance & 4.424 & 6.686 \\
& $(2.224)$ & $(3.709)$ \\
\hline Length of Term & $-1.564 * * *$ & $-1.770 * * *$ \\
& $(.338)$ & $(.353)$ \\
\hline Adj R-squared & .81 & .79 \\
\hline
\end{tabular}

*** Probability less than .001

** Probability less than 0.01

* Probability less than 0.05

When I add (Table 2) their election year measure to the longer time-horizon measures, neither economic measure is statistically significant. This is due to two factors. First, there is a high degree of collinearity between the economic 
measures. The correlation coefficients between the Achen and Bartels [1] measure with the two-year and the Hibbs' measure are respectively .84 and .94. Second, the Achen and Bartels' [1] findings are based on a very small sample $(n=16)$. Thus their results are not very robust. The addition of a single observation, the 2016 election, changes their findings. The 2016 election ran contra to the "time-for-change" model, as the incumbent party's candidate won the popular vote, even though Obama had served two terms. Likewise, the economic performance in the election year (quarters 14 and 15) was below average, $1.10 \%$ growth in per capita disposable income, as opposed to an average growth of $1.16 \%$ in all elections.

Contra to Achen and Bartels [1], the multicollinearity problem, and low $\mathrm{n}(=16)$ precludes a partitioning of effects between the independent variables. Only more data can resolve this multicollinearity problem. At present, the two-year and Hibbs' [36] measures are almost identical to the election measure as indicated in Table 1. Hence, the evidence supports equally both the myopia hypothesis and the non-myopia argument only after non-economic factors are included in the analysis.

There is one positive finding out of these exercises in that they support the multidimensionality of the voter issue space. Any study of economic retrospective voting which only examines the relation between voting and economic conditions is invalid. This finding has implications for the "miracle of aggregation" as formalized in the Condorcet Jury theorem. It assumes a unidimensional issue space; and hence, the evidence, for both economic and non-economic criteria, means that the Condorcet Jury theorem cannot be used to defend epistemic democracy, and relatively uninformed voters.

Having shown that the issue space is multidimensional, I now turn to the problem of ecological inference. All the empirical evidence that voters are myopic relies on aggregate measures of economic performance and electoral outcomes. Hence, they ultimately rely on ecological inference. I now address both issues via a micro-level study which also addresses the issue of a multidimensional issue space.

Hellwig and Marinova [2] conducted a survey which focused on the question of whether voters are myopic. Their survey is the only one, to my knowledge, that tries to test for myopic voting based on subjects' evaluation of a real economic performance and candidates. (Other studies, such as Healy and Lenz [31], conduct experiments based on hypothetical elections.) Hellwig and Marinova [2] specifically asked individuals about their memory of economic events (both short term and long term) in anticipation of the 2012 election. Hence, their study avoids the ecological inference problem discussed above. But, their analysis does not address the issue of a multidimensional issue space. They just analyze an individual's voting intention relative to the economic performance of the incumbent administration. I address both the ecological inference question and multidimensionality of the issue space by analyzing their survey data.

Hellwig and Marinova [2] conducted their own survey to assess whether voters are myopic. They queried individuals as to their perception of the change in economic performance in the preceding 12 months, and Asince the end of 2008". They have four different measures of economic performance: growth, unemployment, inflation and debt. For the present, I just analyze changes in the growth of the economy, because past studies of sociotropic voting find that economic growth is the prime criterion used by voters in making their voting decision.

Their survey asked about recollection of the economy of two different sets of voters. The first group was surveyed as to their vote intention in the 2012 presidential election (Romney or Obama), and their evaluation of economic performance in the last 12 months. A second group was asked as to their vote intention, and recollection of economic performance over the last three years. Thus, we have two samples of size 431 and 455 respectively.

Each individual in both samples was additionally asked about their approval of the incumbent president's performance in office. This is the indicator that I use above to measure the multidimensionality of the issue space. I cannot use Abramowitz's [35] "time-for-change", because the Hellwig and Marinova [2] data are only for one election. So I incorporate it and the perception of past economic performance in analyzing the voting intention of the respondents.

The presidential approval rating has been used to measure the multidimensional issue space. See Erickson and Wlezien, [38], and Lewis-Beck and Stegmaier, [39], for a review of the more general economic voting literature to see how common this has become. I employ a single measure, because it is in the Hellwig and Marinova [2] data set. In this, I follow those analysts that attempt to predict election outcomes, months in advance, by including both the economic conditions at the time, and the incumbent's approval rating (Lewis-Beck and Rice, [40]; Wlezien, and Erikson, [41]; and many others.) A large number of studies have empirically analyzed the approval rating of the president and show that it is correlated with both economic and non-economic factors (Paldam, [42]). A partial list of the findings for non-economic findings is: wars (Mueller, [43]; Verba and Brody, [44]; and Geys, [45]); international relations (Edwards, Mitchell and Welch, [46]); president's integrity (Newman [47]); general policy mood of public and idiosyncratic events (Erikson, MacKuen and Stimson, [48]; and religion (Olson and Warber [49]). 
Table 3. DV: Vote Intention

\begin{tabular}{|c|c|c|}
\hline Model \#1 & Growth $12 \mathrm{mo}$ & Growth3yr \\
\hline Race & $\begin{array}{c}-1.475^{* * *} \\
(.328)\end{array}$ & $\begin{array}{c}-1.614 * * * \\
(.303)\end{array}$ \\
\hline Gender & $\begin{array}{l}.562 * \\
(.221)\end{array}$ & $\begin{array}{l}.636^{* *} \\
(.207)\end{array}$ \\
\hline Income & $\begin{array}{c}-.089^{* *} \\
(.027)\end{array}$ & $\begin{array}{l}-.004 \\
(.026)\end{array}$ \\
\hline Growth & $\begin{array}{c}.936^{* * *} \\
(.130)\end{array}$ & $\begin{array}{c}.551^{* * * *} \\
(.084)\end{array}$ \\
\hline Constant & $\begin{array}{l}1.071^{*} \\
(.474)\end{array}$ & $\begin{array}{c}.738 \\
(.438)\end{array}$ \\
\hline Log Likelihood & -259.503 & -289.655 \\
\hline Pseudo R2 & .164 & .140 \\
\hline \multicolumn{3}{|l|}{ Model \#2 } \\
\hline Race & $\begin{array}{c}.444 \\
(.491) \\
\end{array}$ & $\begin{array}{l}-.754 \\
(.447)\end{array}$ \\
\hline Gender & $\begin{array}{l}-.171 \\
(.366)\end{array}$ & $\begin{array}{l}-.071 \\
(.329)\end{array}$ \\
\hline Income & $\begin{array}{l}-.067 \\
(.046)\end{array}$ & $\begin{array}{c}.021 \\
(.042)\end{array}$ \\
\hline Constant & $\begin{array}{c}-6.592 * * * \\
(1.084)\end{array}$ & $\begin{array}{c}-4.537 * * * \\
(.829)\end{array}$ \\
\hline Growth & $\begin{array}{l}.548^{* *} \\
(.210)\end{array}$ & $\begin{array}{c}.527 * * * \\
(.134)\end{array}$ \\
\hline Approval & $\begin{array}{c}2.943 * * * \\
(.283) \\
\end{array}$ & $\begin{array}{c}2.283 * * * \\
(.203)\end{array}$ \\
\hline Log likelihood & -110.062 & -129.577 \\
\hline Pseudo R2 & .637 & .589 \\
\hline
\end{tabular}

Some of the studies supporting myopic voting, (for example, Kramer, [12]; Fair, [13]; Nordhaus, [11]) include controls for non-economic factors; but, almost exclusively they are just war and/or a time measure. They do not control for a broad range of factors, e.g., integrity, religion, policy mood, international relations, etc., that affect the voting decision. It is argued that gay rights, abortion, immigration policy are short-term idiosyncratic factors that affect candidate choice, but they can be ignored, because we cannot anticipate them, and hence, measure them (Hibbs, [50]). The importance of abortion, the civil rights movement, the southern strategy, etc., cannot be ignored, if even some believe they are short-term. The president's approval rating, as noted above, is found to be the single, most comprehensive measure reflecting all of these criteria.

Table 3 reports my findings. The baseline model (Model \#1) compares the voting intention of those who were asked about their recollection of economic growth in the preceding 12 months versus the group who were asked about their recollection of economic growth over the entire administration.

In addition to the economic performance measures, I added controls for race, gender and income. The expected sign of the race and gender measures is positive. Minorities and women are more likely to support Obama. But the wealthier voters are more likely to support Romney.

Both economic performance measures (short and long-term) are the hypothesized positive sign, i.e., the higher the perception of growth in the economy, the more likely individuals are to support the incumbent president's party candidate. The difference between the two, in terms of explained variance, is minimal. Hence, the evidence is inconclusive regarding the myopia hypothesis.

Model \#2 introduces my control for the multidimensional issue space. The approval rating of the president is assumed to reflect not only his performance in terms of the economy, but also other issues such as health care and foreign affairs, as found in exit polls from the 2012 election.

Three features stand out. First, the control variables (race, gender and income) are no longer statistically significant. The individual's approval rating now captures the fact that minorities and women are more supportive of Obama; while, the wealthy are less likely to support Obama.

Second, there is a substantial increase in the explained variance, as measured by either the reduction in the log likelihood measure or the pseudo-R2, with the inclusion of the approval measure. The exit polls in 2012 asked respondents what was their most important issue in the election. Romney was perceived as better for the economy by a majority of voters; while Obama won based on his health care and foreign policies (Edison Research, [51]). Thus, the multidimensionality hypothesis is substantiated at the individual level.

Additionally, the substantially increased explained variance by the approval measure is not because the approval measure reflects perception of past economic performance. Model \#1 captures the effect of economic performance on vote intention. The addition of the approval measure increases the link to vote intention above and beyond that related to economic performance.

Third, the explained variance measures for the measures (long and short term) of economic performance are about equal. But, the three-year measure is somewhat smaller. Hence, the question arises whether this might be evidence for the myopia hypothesis.

One procedure to determine whether the difference between the two reflects a myopia bias is to perform an interaction test. In this, I follow Hellwig and Marinova [2], but with the addition of the approval measure to control for multidimensionality. The data set for this analysis combines the two sample groups (both 12 months, and entire administration) such that there is a positive or negative evaluation, irrespective of the time-horizon of the evaluation.

The interaction logit equation is:

Vote Intention $=\mathrm{b} 0+\mathrm{b} 1($ Economic Performance $)+$ b2 (Long Term: dummy $1=$ long term, $0=$ short term $)+$ b3 $\left(\mathrm{LT}^{*}\right.$ Economic Performance $)+\mathrm{b} 4($ Approval $)+\varepsilon$

If $\mathrm{b} 1+\mathrm{b} 3$ are $<0$, then the myopia hypothesis is supported. However, if $\mathrm{b} 1+\mathrm{b} 3>0$, then the myopia hypothesis is rejected. 
Table 4. Interaction Model

\begin{tabular}{|c|c|}
\hline Model \#3: & DV: Vote Intention \\
\hline Economic Performance: & $1.69 * * *$ \\
Combined Measure & $(0.39)$ \\
\hline Long-Term (3 yr.) & 1.22 \\
& $(0.34)$ \\
\hline LT*Econ Performance & 0.89 \\
& $(.25)$ \\
\hline Partisan Identification & $0.50 * * *$ \\
& $(0.04)$ \\
\hline Approval & $7.39 * * *$ \\
& $(1.28)$ \\
\hline Log likelihood & -193.16 \\
\hline Pseudo R2 & 0.69 \\
\hline $\mathrm{N}$ & 898 \\
\hline
\end{tabular}

As shown in Table 4 (Model \#3) both b1 and b3 are positive. But, only b1 is statistically significant. The interactive term is positive and would indicate a positive boost from the long-term perspective to voting intention if it were statistically significant. Being statistically insignificant, it provides neither a boost nor a reduction in vote intention based on long-term performance. Thus, my findings with respects the myopia hypothesis is identical to that of Hellwig and Marinova [2] and rejects the myopia hypothesis. And again, as in Model \#2, the approval measure is the only other significant relationship.

The addition of the approval measure results in models which produce almost identical levels of explained variance. The question is why there is a convergence between the two different measures of economic performance. This convergence suggests that administrations and/or their challengers can address either economic or non-economic issues simultaneously or interchangeably. If doing poorly in terms of economic performance, the administration can shift attention to non-economic issues. For example, Reagan, facing a poor economy in the first half of his term, decided to invade Grenada in 1983, which increased his approval rating. Likewise, with a strong economy under Clinton, the Republicans used Whitewater to attack Clinton's approval rating. As noted by Riker [52], with a multidimensional issue space, competitors frequently try to introduce new issues or change issues in order to defeat an opponent. There is no equilibrium strategy in a multidimensional issue space (McKelvey [53]). Contenders are constantly looking for weaknesses in their opponent. Thus, an increase in one metric is regularly offset by the opposition by raising another dimension.

Any analysis of voters' criteria in evaluating incumbents must acknowledge that voters use multiple criteria, i.e., that the issue space is multidimensional, not unidimensional. Just analyzing voting as a unidimensional issue space, and thus using a single indicator, is likely to produce incorrect inferences.
Table 5A. Wolter, Hansen, Campbell and Ansolabehere [53]: Who is most responsible for perceived poor state of the economy in 2012

\begin{tabular}{|c|c|}
\hline & Deserves Greatest Blame \\
\hline President Barack Obama & \\
\hline President George W. Bush & $22.1 \%$ \\
\hline Congressional Republicans & $24.1 \%$ \\
\hline Federal Reserve Bank & $8.5 \%$ \\
\hline Banks & $5.2 \%$ \\
\hline
\end{tabular}

Table 5B. CNN/ORC Poll (Edison Research, 2014)

Q: Who is most responsible for the poor state of the economy?

\begin{tabular}{|c|c|c|c|c|}
\hline & $\begin{array}{c}\text { Obama } \\
\text { \& Dems }\end{array}$ & $\begin{array}{c}\text { Bush \& } \\
\text { Reps }\end{array}$ & $\begin{array}{c}\text { Both } \\
\text { Equally }\end{array}$ & Neither \\
\hline Sept., 2010 & $33 \%$ & $53 \%$ & $10 \%$ & $3 \%$ \\
\hline Sept. 2012 & $35 \%$ & $57 \%$ & $6 \%$ & $2 \%$ \\
\hline Sept. 2014 & $34 \%$ & $44 \%$ & $14 \%$ & $5 \%$ \\
\hline
\end{tabular}

Lastly, a couple of polls (Table 5A and B) present a less ambiguous picture of memory length, and reject the inference that voters are myopic. Starting in 2010, NORC started asking individuals who they blamed for the poor state of the economy (Edison Research, [50] and Wolter et al. [53]. Wolter et al [53] found that $50 \%$ blamed banks; $24 \%$ blamed Bush; and 22\% blamed Obama during the 2012 election. Edison Research [51] also polled prospective voters, but they did not have banks as an option. They found 57\% blamed Bush and the Republicans for the state of the economy in 2012. As late as January of 2014, $44 \%$ of voters still held Bush or the Republicans responsible for the Great Recession, and the continued economic malaise. Only 33\% blamed Obama and the Democrats. These polls show that voters are not myopic; they remembered who was in power in 2008 when the Great Recession broke out. They have a longer memory than implied by most studies.

The limitation of these two polls is that they do not ascertain whether the respondents voted or abstained; and do not control for non-economic issues. Hence, they do not determine whether memory length affects vote choice. The same problem plagues the Hellwig and Marinova [2] study, as they cannot differentiate voters from abstainers. But, studies show that the better informed or knowledgeable an individual, the more likely they are to vote (Denny and Doyle [55], Lassen [56]). Thus, one can infer that individuals with long-memories will vote with higher probability than less informed individuals. Lastly, these polls do show that the majority of average individuals have a longer memory of past economic condition than assumed by supporters of the myopia hypothesis. And thus, there is strong evidence for rejecting the myopia hypothesis. 


\section{Discussion}

Past tests of myopic voting are plagued by two limitations: the ecological inference problem and absence of adequate controls for multidimensionality. All the empirical evidence for myopic voting is based on aggregate data, and hence, subject to the ecological fallacy problem (Kramer, [21]). The Hellwig and Marinova [2] is the only study that avoids this problem by conducting a micro-level survey which measures individual perceptions (long and short term) of administration economic performance. However, their analysis does not address the multidimensionality of the issue space. Even after I introduce a control for multidimensionality in the Hellwig and Marinova [2] data, we cannot either accept or reject the myopia hypothesis. Some respondents have some long-term and short-term memories. And they appear to be approximately equal in number. The same holds for the Achen and Bartels [1] analysis, as three of their economic measures (election year, two year, and Hibbs' [36] discounted four year) as they produce almost identical predictions of the margin of victory.

Only the polls of Edison Research [51] and Wolters et al. [54] show conclusively that the majority of individuals have long-term memories of economic conditions.

My critique of the myopia characterization is also supported by a number of indirect studies. Bechtel and Hainmueller [57] find the persistence for six years of electoral support for a government which performed well in response to a natural catastrophe. Suzuki and Chappell [58] present evidence that voters respond to permanent (long-term) not cyclical (short-term) changes in the economy. Lastly, "issue ownership" (Petrocik, [59]) requires voters have a long-term memory of party performance to determine that one party owns an issue such as economic performance.

There are still a number of caveats with respects my findings. First, follow up studies to the Hellwig and Marinova [2] analysis are needed. Modifications in their research design are required in the form of: one, asking the short and long-term perceptions of the same individuals would attenuate the possibility of framing effects; two, there must be better controls for actual turnout, as it has been shown that less informed voters are less likely to vote.

Second, the rejection of the myopia claim needs additional evidence, because the approval rating of presidents might be based on short-term considerations. Even though there is a substantial literature showing that the approval rating is determined by many non-economic issues, there is no direct test of whether these non-economic factors have a long or short-term impact. The closest we have is the study by Edwards, Mitchell and
Welch [46] that the salience of issues changes over time; war and international issues can dominate for a time, and then the economy, and then domestic issues, such as civil rights. Clearly, research is needed to determine whether non-economic factors affecting the president's approval rating persist over time, or are short-lived. Likewise, Abramowitz's [35] "time-for-change" measure is a black box explanation. We must determine what factors, economic or non-economic, that produce the effect.

\section{Appendix}

Because of the small sample size in Table 1, extra care is required when evaluating the findings. Hence, I perform four sensitivity tests of the relationships. A standard test of robustness is to drop part of the sample and ascertain whether the remainder of the sample reproduces the same findings. Table A1 presents the findings of the four sensitivity tests.

I first dropped the 1952 and 1956 elections from the sample, because the Eisenhower candidacy might be exceptional. He was, during WWII, the Commander in Chief of Allied Forces in Europe. With 24 million veterans voting, they might have voted for him, not because of the economy, but rather because he was their former Commander in Chief. Table A1, section A.1.A indicates Eisenhower's candidacy did not make a difference, as the economy and the time-for-change measures have the same impact as when the 1952 and 1956 elections are included in the sample.

Next, I dropped the 2012 and 2016 elections from the sample, because of the atypical low economic growth rates after the Great Recession. Table A1, section A.1.B indicates again that dropping these two elections from the sample, does not change the analysis.

Next, I dropped the 1972 election, because Tufte [14] shows that Nixon made extraordinary efforts to insure his reelection. As indicated in Table A1, section A.1.C, the dropping of the 1972 election does not change the analysis.

Lastly, I dropped the 1964 election because it had the largest margin of victory for the incumbent (23\%). Johnson might have won a landslide victory over Goldwater, because of Goldwater's "southern strategy" and not the economy. Again, the 1964 election was not atypical.

Thus, all four sensitivity tests affirm the robustness of the rejection of the myopia hypothesis in Table 1 . The only difference in findings is that the three-year performance, which is not statistically significant in the full data set, is statistically significant when observations are dropped from the sample. But it is the least predictive of the electoral vote, as measured by r-squared. 
Table A.1. Sensitivity Tests

\begin{tabular}{|c|c|c|c|c|}
\hline A.1.A & Election Year & Last 2 years & Last 3 years & Hibbs $(80 \%)$ \\
\hline Economic Performance & $\begin{array}{c}7.015^{* * *} \\
(0.958)\end{array}$ & $\begin{array}{c}2.759 * * * \\
(0.559)\end{array}$ & $\begin{array}{l}2.053^{*} \\
(0.659)\end{array}$ & $\begin{array}{c}4.046^{* * *} \\
(0.808)\end{array}$ \\
\hline Time for Change & $\begin{array}{c}-1.380^{* *} \\
(0.431) \\
\end{array}$ & $\begin{array}{l}-1.579^{*} \\
(0.572) \\
\end{array}$ & $\begin{array}{l}-1.307 \\
(0.806) \\
\end{array}$ & $\begin{array}{l}-1.525^{*} \\
(4.864) \\
\end{array}$ \\
\hline Constant & $\begin{array}{c}5.350 \\
(3.352)\end{array}$ & $\begin{array}{c}3.097 \\
(4.908)\end{array}$ & $\begin{array}{c}0.971 \\
(7.540)\end{array}$ & $\begin{array}{c}3.006 \\
(4.864)\end{array}$ \\
\hline Adj R-squared & .85 & .73 & .56 & .73 \\
\hline \multicolumn{5}{|l|}{ A.1.B } \\
\hline Economic Performance & $\begin{array}{c}6.477 * * * \\
(1.139)\end{array}$ & $\begin{array}{c}2.876^{* * * *} \\
(0.575)\end{array}$ & $\begin{array}{l}1.889 * * \\
(0.548)\end{array}$ & $\begin{array}{c}1.399 * * * \\
(0.858)\end{array}$ \\
\hline Time for Change & $\begin{array}{c}-1.763^{* * *} \\
(0.310) \\
\end{array}$ & $\begin{array}{c}-1.200^{* *} \\
(0.348) \\
\end{array}$ & $\begin{array}{c}-1.737^{* *} \\
(0.422) \\
\end{array}$ & $\begin{array}{c}-1.407 * * \\
(0.348) \\
\end{array}$ \\
\hline Constant & $\begin{array}{l}9.041 * * \\
(2.833) \\
\end{array}$ & $\begin{array}{c}0.431 \\
(4.169) \\
\end{array}$ & $\begin{array}{l}4.855 \\
(4.73) \\
\end{array}$ & $\begin{array}{c}2.340 \\
(3.988) \\
\end{array}$ \\
\hline Adj R-squared & .81 & .77 & .64 & .76 \\
\hline \multicolumn{5}{|l|}{ A.1.C } \\
\hline Economic Performance & $\begin{array}{c}6.021 * * * \\
(1.068)\end{array}$ & $\begin{array}{c}2.651^{* * * *} \\
(0.483)\end{array}$ & $\begin{array}{l}1.731^{* * *} \\
(0.515)\end{array}$ & $\begin{array}{c}3.826 * * * \\
(0.722)\end{array}$ \\
\hline Time for Change & $\begin{array}{c}-1.669 * * * \\
(0.282) \\
\end{array}$ & $\begin{array}{c}-1.120^{* *} \\
(0.287) \\
\end{array}$ & $\begin{array}{c}-1.581^{* *} \\
(0.390) \\
\end{array}$ & $\begin{array}{c}-1.310^{* *} \\
(0.290)\end{array}$ \\
\hline Constant & $\begin{array}{l}8.488^{* *} \\
(2.430) \\
\end{array}$ & $\begin{array}{c}0.279 \\
(3.381) \\
\end{array}$ & $\begin{array}{c}3.987 \\
(4.163) \\
\end{array}$ & $\begin{array}{c}2.096 \\
(3.145) \\
\end{array}$ \\
\hline Adj R-squared & .78 & .78 & .61 & .77 \\
\hline \multicolumn{5}{|l|}{ A.1.D } \\
\hline Economic Performance & $\begin{array}{c}6.574 * * * \\
(1.262) \\
\end{array}$ & $\begin{array}{c}2.677 * * * \\
(0.565) \\
\end{array}$ & $\begin{array}{l}1.716^{* *} \\
(0.555) \\
\end{array}$ & $\begin{array}{l}3.940 * * \\
(0.888) \\
\end{array}$ \\
\hline Time for Change & $\begin{array}{c}-1.771 * * * \\
(0.305)\end{array}$ & $\begin{array}{c}-1.1 .71 * * \\
(0.318)\end{array}$ & $\begin{array}{c}-1611^{* *} \\
(0.410)\end{array}$ & $\begin{array}{c}-1.384 * * \\
(0.328)\end{array}$ \\
\hline Constant & $\begin{array}{c}9.001 \\
(4.352) \\
\end{array}$ & $\begin{array}{c}0.812 \\
(3.658) \\
\end{array}$ & $\begin{array}{c}4.396 \\
(4.352) \\
\end{array}$ & $\begin{array}{c}2.713 \\
(3.358) \\
\end{array}$ \\
\hline Adj R-squared & .76 & .73 & .58 & .70 \\
\hline
\end{tabular}

\section{REFERENCES}

[1] Christopher Achen, Larry Bartels. Democracy for Realists, Princeton University Press, Princeton, NJ, 2016.

[2] Timothy Hellwig, Dani Marinova. More Misinformed than Myopic: Economic Retrospections and the Voter's Time Horizon, Political Behavior, Vol. 37, No. 4, 865-87, 2015.

[3] Angus Campbell, Philip Converse, Warren Miller, Donald Stokes. The American Voter, Wiley, New York, NY, 1960.

[4] Gary Jacobson. Does the Economy Matter in Midterm Elections, American Journal of Political Science, Vol. 34, No. 2, 400-404, 1990.

[5] W. Lance Bennett. The Growth of Knowledge in Mass Belief Studies, American Journal of Political Science, Vol. 21, No. 7, 465-500, 1977.

[6] Michael Delli Carpini, Scott Keeter. What Americans Know About Politics and Why It Matters, Yale University Press, New Haven, CT, 1996.
[7] Bryan Caplan. The Myth of the Rational Voter, Princeton University Press, Princeton, NJ, 2007.

[8] Ilya Somin. Democracy and Political Ignorance. Stanford University Press, Stanford, CA, 2013.

[9] Morris Fiorina. Retrospective Voting in American Presidential Elections, Yale University Press, New Haven, CT, 1981.

[10] William Riker. Liberalism against Populism: A Confrontation between the Theory of Democracy and the Theory of Social Change, Freeman, San Francisco, CA, 1982.

[11] William Nordhaus. The Political Business Cycle, the Review of Economics Studies, Vol. 42, No. 2, 169-90, 1975.

[12] Gerald Kramer. Short-Term Fluctuations in US Voting Behavior, 1896-1964, The American Political Science Review, Vol. 65, No. 1, 134-43, 1971.

[13] Ray Fair. The Effect of Economic Events on Votes for President, The Review of Economics and Statistics, Vol. 10, No. 2, 159-73, 1978.

[14] Edward Tufte. Political Control of the Economy, Princeton University Press, Princeton, NJ, 1975. 
[15] Christopher Achen, Larry Bartels. Musical Chairs: Pocketbook Voting and the Limits of Democratic Accountability, Working Paper, Princeton University, 2004.

[16] Larry Bartels. Unequal Democracy, Princeton University Press, Princeton, NJ, 2008.

[17] E. E. Schattschneider. The Semi-Sovereign People, Holt, Reinhart and Winston, New York, NY, 1960.

[18] Kay Schlozman, Sidney Verba, Henry Brady. The Unheavenly Chorus, Princeton University Press, Princeton, NJ, 2012.

[19] Mancur Olson. The Logic of Collective Action, Harvard University Press, Cambridge, MA, 1965.

[20] Kenneth Arrow. Social Choice and Individual Value, Yale University Press, New Haven, CT, 1954.

[21] Gerald Kramer. The Ecological Fallacy Revisited: Aggregate- versus- Individual-level Findings on Economics and Elections, and Sociotropic Voting, American Political Science Review, Vol. 77, No. 1, 92-111, 1983.

[22] Anthony Downs. An Economic Theory of Democracy, Harper \& Row, New York, NY, 1957.

[23] Richard Jankowski. Altruism and Self-Interest in Democracies, Palgrave Macmillan, New York, NY, 2015.

[24] Alberto Alesina, Howard Rosenthal. Partisan Politics, Divided Government, and the Economy, Cambridge University Press, New York, NY, 1995.

[25] Michael MacKuen, Robert Erikson, James Stimson. Peasants or Bankers? The American Electorate and the U.S. Economy, The American Political Science Review, Vol. 86, No. 3, 597-611, 1992.

[26] Christopher Sims. Money, Income, and Causality, The American Economic Review, Vol. 62, No. 4, 540-52, 1972.

[27] Christopher Sims. Uncertainty in the Monetary Aggregates: Sources, Measurement, and Policy: Discussion, The Journal of Finance, Vol. 36, No. 2, 515-17, 1981. Papers and Proceedings of the Thirty Ninth Annual Meeting of the American Finance Association, Denver, September 5-7, 1980

[28] Yianis Sarafidis. What Have You Done for Me Lately? Release of Information and Strategic Manipulation of Memories, The Economic Journal, Vol. 117, No. 518, 307-26, 2007.

[29] Mark Kayser, Michael Peress. Benchmarking Across Borders: Electoral Accountability and the Necessity of Comparison, The American Political Science Review, Vol. 106, No. 3, 661-684, 2012

[30] Matthew Gentzkow. Television and Voter Turnout, The Quarterly Journal of Economics, Vol. 121, No. 3 (Aug.), 931-72, 2006.

[31] Andrew Healy, Gabriel Lenz. Substituting the End for the Whole: Why Voters Respond Primarily to the Election-Year Economy, The American Journal of Political Science, Vol. 58, No. 1, 31-47, 2014.

[32] Alberto Alesina, John Londregan, Howard Rosenthal. A Model of the Political Economy of the United States, The
American Political Science Review, Vol. 87, No. 1, 12-33, 1993.

[33] Paul Krugman. It's Back, Japan and the Liquidity Trap, Brookings Papers, Vol. 1998, No. 2, 137-205, 1998.

[34] Blinder, Alan and Mark Watson. Presidents and the U.S Economy: An Econometric Exploration, American Economic Review, Vol. 106, no. 4, pp. 1015-45, 2016.

[35] Alan Abramowitz. Forecasting the 2008 Presidential Election with the Time-for-Change Model, PS: Political Science Journal, Vol. 41, No. 4, 691-95, 2008.

[36] Douglas Hibbs. The American Political Economy, Harvard University Press, Cambridge, MA, 1987.

[37] Christopher Wlezien. The Myopic Voter? The Economy and US Presidential Elections, Electoral Studies, Vol. 39, (September), 195-204, 2015

[38] Robert Erickson, Christopher Wlezien. The Timing of Presidential Elections, University of Chicago Press, Chicago, IL, 2012.

[39] Michael Lewis-Beck, Mary Stegmaier. Economic Determinants of Electoral Outcomes, Annual Review of Political Science, Vol. 3, (June), 183-219, 2000.

[40] Michael Lewis-Beck, Tom Rice. Presidential Popularity and Presidential Vote, Public Opinion Quarterly, Vol. 46, No. 2, 534-37, 1982

[41] Christopher Wlezien, Robert Erickson. Temporal Horizons and Presidential Elections Forecasts, American Politics Research Quarterly, Vol. 24, No. 4, 492-505, 1996.

[42] Martin Paldam. Vote and Popularity Functions. In Charles Rowley and Frederick Schneider (eds.), Readings in Public Choice and Constitutional Political Economy, Springer, New York, NY, 2008.

[43] John Mueller. American Public Opinion and the Gulf War: Some Policy Issues, Public Opinion Quarterly, Vol. 57, No. 1, 80-91, 1993.

[44] Sidney Verba and Richard Brody. Participation, Policy Preference, and the War in Vietnam, Vol. 34, No. 3, 325-32, 1970.

[45] Benny Geys. War, Presidents, and Popularity: The Political Cost(s) of War Re-examined, Public Opinion Quarterly, Vol. 74 , No. 2, 357-74, 2010

[46] George Edwards III, William Mitchell, Reed Welch. Explaining Presidential Approval: The Significance of Issue Salience, American Journal of Political Science, Vol. 39, No. $1,108-34,1995$

[47] Brian Newman. Integrity and Presidential Approval, 1980-2000, The Public Opinion Quarterly, Vol. 67, No. 3, $335-67,2003$

[48] Robert Erickson, Michael MacKuen, James Stimson, Macropolity, Cambridge University Press, Cambridge, UK, 2002.

[49] Laura Olson, Adam Warber. Belonging, Behaving, and Believing: Assessing the Role of Religion on Presidential Approval, Political Research Quarterly, Vol. 61, No. 2, 192-204, 2008. 
[50] Douglas Hibbs. Obama's Reelection Prospects Under "Bread and Peace" Voting in the 2012 US Presidential Election, PS: Political Science and Politics, Vol. 45, No. 4, 635-39, 2012.

[51] Edison Research. The National Election Pool Partnership, CNN/ORC, Poll \#3, 2014.

[52] William Riker. The Art of Political Manipulation, Yale University Press, New Haven, CT, 1986.

[53] Richard McKelvey. Intransitivities in Multidimensional Voting Models and Some Implications for Agenda Control, Journal of Economic Theory, Vol, 12, No. 3, 472-82, 1976.

[54] Kirk Wolter, Mark Hansen, Andrea Campbell, Stephen Ansolabehere. 2012 NORC Presidential Election Survey, 2013.

[55] Kevin Denny, Orla Doyle. Political Interest, Cognitive
Ability and Personality: Determinants of Voter Turnout in Britain, British Journal of Political Science, Vol. 38, No. 2 (Apr.), 291-310, 2008.

[56] David Lassen. The Effect of Information on Voter Turnout: Evidence from a Natural Experiment, American Journal of Political Science, Vol. 49, No. 1 (Jan.), 103-118, 2005.

[57] Michael Bechtel, Jens Hainmueller. How Lasting is Voter Gratitude? An Analysis of the Short and Long Term Electoral Returns to Beneficial Policy, American Journal of Political Science, Vol. 55, No. 4, 852-68, 2011.

[58] Motoshi Suzuki, Henry Chappell. The Rationality of Economic Voting Reconsidered, Journal of Politics, Vol. 58, No. 1, 224-36, 1996.

[59] John Petrocik. Issue Ownership in Presidential Elections, with a 1980 Case Study, American Journal of Political Science, Vol. 40, No. 4, 825-850, 1996. 